\title{
A Critique of Stephen Downes' Article, "Learning Objects": A Perspective from Bahrain
}

\begin{abstract}
Muain Jamlan
With the availability of technology, hardware and software, learning objects become fundamental to the learning process and change the way in which learning materials are designed. The vast development of technology forces both teacher and learner to modify their roles. Teachers become facilitators while learners became active and responsible for selecting modes and styles of learning. Assuming this attitude of implementing technology in the learning process and seeking new methods of facilitating learning, universities and colleges have to adopt new techniques. One of these new techniques is the use of learning objects. Although learning objects are considered products of technology developed in the USA, Japan, and European countries, universities in the Middle East have also been influenced by this development. While there are differences in the quantity and quality of these technologies available in Middle East countries, computer applications, especially those that deploy the Internet, have now become available. Educational authorities in Middle East countries are now turning to the availability of learning objects. Let me clarify some of the issues Downes discusses in his article on learning objects, Vol. 2, No. 1 of the International Review of Research in Open and Distance Learning.
\end{abstract}

\section{Targeting general courses taught in universities}

Downes discusses the example of general courses taught in all universities, and how universities teaching similar courses can use learning objects. Distance learning universities in the Middle East can adopt this idea by unifying their efforts to teach the same course through the same technology. Unfortunately, distance learning universities and other institutions in the area offer different courses and are not always aware of the courses taught by others. Let us then share the same courses, work on generalizing them, and offer them in universities if possible. This will save time, effort and cost.

\section{Using similar learning objects technology}

Technology is costly in the Middle East; not every country in the area can afford expensive technology. Sharing technology between distance learning institutions can be a cost-effective way to respond to the increasing demand for learning 
opportunities. In the Middle East many technologies can be shared, including television broadcasting via satellite, computer technology and so on. Some distance learning universities still use the book and older technologies, whereas others are trying to catch up with newer technologies. If institutions decided to work together, technologies could be shared among these institutions easily.

\section{Less Cost}

Not all Middle East countries can afford new technologies, and each distance learning institution has to apply the technologies it can afford. In the meantime sharing technologies can minimize cost. Some rich Middle East countries can afford technology easily, as financial support is available, whereas in some other unlucky ones technology is hardly available. Sharing learning objects and other technologies among rich and poor countries would help distance learning institutions to fulfill needs. Costs of online learning may also vary from one country to another. Distance learning institutions in the Middle East have the same mission. But because their approaches and applications vary, it would be difficult for them to adopt the same policies, terminologies and learning objects.

Although some distance learning institutions are utilizing multimedia and learning objects to deliver web-based courses, many institutions are still dependant upon the older technologies and traditional ways of learning. Moving to new technologies for some institutions represents a formidable cost. I agree with Downes that through unification of their efforts to teach common courses, and share the same technology (including learning objects), costs can be minimized.

Citation Format

Jamlan, Muain (July, 2001) A Critique of Stephen Downes' Article, "Learning Objects": A Perspective from Bahrain. International Review of Research in Open and Distance Learning: 2, 1. http://www.icaap.org/iuicode?149.2.1.12 